\title{
Early Childhood Education and Child Development Outcomes in Least Developed Countries: Empirical Evidence from Lao PDR
}

\author{
Manivone Phongsopha ${ }^{1} \&$ Piriya Pholphirul ${ }^{1}$ \\ ${ }^{1}$ Graduate School of Development Economics, National Institute of Development Administration, Thailand \\ Correspondence: Piriya Pholphirul, Graduate School of Development Economics, National Institute of \\ Development Administration, Serithai Road, Klong-Chan, Bangkapi, Bangkok 10240, Thailand. Tel: \\ 66-081-171-3213. E-mail: piriya@nida.ac.th
}

$\begin{array}{rrr}\text { Received: April 15, } 2018 & \text { Accepted: May 2, } 2018 & \text { Online Published: May 28, } 2018 \\ \text { doi:10.5539/ass.v14n6p131 } & \text { URL: https://doi.org/10.5539/ass.v14n6p131 }\end{array}$

\begin{abstract}
Given the benefits of early childhood education, many countries try to ensure universal accessibility to early childhood education. However, with their limited budgets and chronic poverty, least developed countries face a huge disadvantage in providing access to early childhood education, especially for children of lower income families and those living in remote areas. This study aims to determine how accessibility to early childhood education and child development affects cognitive, learning, physical, and social-emotional readiness. We use nationally representative data from the Lao Social Indicator Survey (LSIS) for a case study of Lao PDR, which is representative of least-developed countries. Our estimation indicates that mother's educational attainment and economic status of the family have an important impact on children's preschool enrollment. In terms of children's development, receiving early childhood education is likely to play a significant role in developing cognitive skills. Furthermore, in addition to early childhood education per se, activities associated such education also play an important role in fostering children's development. Hence, early childhood education should be promoted in order to enhance all children's access to preschools and thus ensure that their development remains on track.
\end{abstract}

Keywords: early childhood education, child development, education inequality, least developed countries, Lao PDR

\section{Introduction}

Education is viewed as an investment in human capital that enhances the nature of individuals' lives in ways that bring advantages to their personal and economic prosperity (Acemoglu \& Autor, 2011). Even though at the national level increasing educational attainment may not appear to return measureable positive economic outcomes, when human capital is measured in terms of cognitive skills, the benefits become more apparent (Hanushek \& Woessmann, 2012). Heckman (2012) has shown that the critical time for strengthening cognitive skills is from birth to age five, when the brain grows quickly as it establishes the cognitive capabilities and character traits fundamental for proper achievement. According to the World Bank, this process has five steps, called "STEP" (Skills Toward Employment and Productivity). ${ }^{1}$ The first step, "getting children off to the right start," is crucial for human productivity and lifelong learning and needs to occur early in a child's life.

Accordingly, early childhood education, including ensuring access to preschool, has been given policy precedence in various countries. The considerable transformation that occurs in preschool may concentrate on one or several aspects of children's development (UNESCO, 2006). For example, learning early in life is essential for development of those human skills that are needed in the long term (Opel, Ameer, \& Aboud, 2009). In addition, the beneficial outcome of attending preschool has been found to lower the chance of early drop-out and grade failure, as well as to increase IQ scores(Berlinski, Galiani, \& Manacorda, 2008) ${ }^{2}$.

In developed countries, for example, the United Kingdom, with its Effective Provision of Pre-school Education (EPPE) project, children's intellectual and social-emotional well-being were enhanced and the good results of this evidenced during their first three years in primary education ${ }^{3}$. Nevertheless, the activities of parents and children played an important role in helping children, especially disadvantaged children, to develop on track (Siraj-Blatchford et al., 2004). Furthermore, in the United States there are special public programs such as the "Carolina Abecedarian Project", the "Chicago Child-Parent Center Program", , and the "Perry Preschool 
Project" ${ }^{\prime 6}$ which focus on supporting children's development and creating opportunities for children from economically disadvantaged families. Additionally, MacEwan (2013) has studied the cost-benefit analysis of these three programs and found that children who participated in such programs tended to do better in their studies, have lower rates of premature pregnancy, to be less likely to be involved in crime, and to have occupations with higher earnings than did kids who did not participate in preschool programs.

In recognition of the importance of early childhood intervention, Sweden's National Curriculum for Preschool, which emphasizes lifelong learning, has provided free pre-primary education for children from ages one to five, ensuring that all children get the same opportunities in life regardless of the economic status of their family. In addition, Stoop (2011) found that in New Zealand a specific preschool education is required for every child at least three years old to make sure that the child grows up with skills and learning abilities.

However, due to the fact many developing and least-developed countries are still facing severe economic restrictions that aggravate education inequality, 159 million children, or half of all age three-to-six-year-olds across the world, do not have access to early childhood education, and more than 200 million children under five bear of developmental loss. Although developing countries have expanded access to preschool and there has been an increase in pre-primary enrollment in all regions over the past decade, today children from the poorest families are still largely unable to gain access (World Bank, 2015).Unequal access to early childhood education also has a negative effect on cognitive development and reduces the readiness to learn at the primary education level (Anderson et al., 2003). Moreover, in developing countries children from rich families are much more likely to go to preschool than are children from poor families, resulting in disadvantages in the proper development of these children (Nonoyama-Tarumi \& Ota, 2011).

Mexico is, for example, a developing country that made pre-primary education compulsory in 2002, yet unequal access remains a challenge as is the fact that there are public preschools which have poor facilities, few resources, and less-qualified teachers (Santibañez, Vernez, \& Razquin, 2005). Corresponding to the advantages of early childhood education, Pholphirul (2017) assessed the access to and the long term benefits of pre-primary education for Thai students by using test scores from PISA. Even though results indicated that early childhood education had a significant effect on scoresin reading, mathematics, and science when the children reached age 15 , unequal access to pre-primary education remained a major obstacle for Thai children to reap benefits from attending preschool.

Given the benefits of pre-primary education, both in developed and developing countries, it would seem to make sense to make early childhood education universally available, especially to disadvantaged children. However, with limited budgets and chronic poverty, least developed countries face a huge disadvantage with regard to providing access to preschool education for lower income families and for children in remote areas. Bangladesh, for example, is a least developed country in which disadvantaged children have low rates of access to preschool education because, evidently, no department or ministry of education has taken seriously enough the issue of preschool education at the national level (Nath \& Sylva, 2007). In Cambodia, for example, where Rao and Pearson (2007) examined childcare and education policies, 80 percent of Cambodians live in rural areas, yet almost no rural children are enrolled in early childhood education.

Likewise, Lao PDR, a country with many ethnic and linguistic groups, still has some of poorest education indicators in Southeast Asia (King, 2010). This demographic diversity results in unbalanced opportunity for early childhood education across the various ethnic groups. Only about 30 percent of the total population of formal preschool education age attended preschools in 2014. Moreover, since preschool education is not compulsory, parents themselves need to decide whether to send their child to preschool (UNICEF, 2012).

Even though the Ministry of Education and Sport of Lao PDR reported that the number of students enrolled in public early childhood education increased to 125,770 and that 33,721 children were enrolled in private schools due to increase thecommunity-based programs, nearly 60 percent of private early childhood education enrollment was only in Vientiane, the capital city, and in two provinces in the north (Saravan and Phongsaly) were no private early childhood education so arr $^{7}$.

Differences in the management of preschool education programs between early childhood education centers and community-based programs bring up research questions regarding how to 1) estimate the probability of access to early childhood education and 2) whether children who receive early childhood education do in fact make progress of child development outcomes. Although there were some short-term and long-term studies assessing these qualities, studies using a national representative survey dataset are still rare.

The paper is divided into four parts. The next section assesses Lao children's access to early childhood education. The third section quantifies the impacts of childhood education on child development outcomes. The last section 
provides conclusions and policy recommendations.

\section{The Accessibility of Early Childhood Education in Lao PDR}

This study employed surveyed data from the Lao Social Indicator Survey (LSIS) which was conducted during the year 2011-2012 ${ }^{8}$. Nationally representative data can suggest appropriate remedial policies for the nation as opposed to studies based on a specific group of children, which can cause difficulties when formulating recommendations for policies at a national level. The data contains in form of cross-sectional data of 3,869 children. Questions focused on three- and four-year-olds to assess their early learning by determining whether they currently attended any organized learning or early childhood education program, including kindergarten or community child care ${ }^{9}$. This article examines the level of accessibility to early childhood education by gender, place of residence, ethnicity, language, mother's education, father's education, and household wealth ${ }^{10}$.

Descriptive statistics (Table 1) show that, from the sample of 3,869 children, around half had access to preschool education (47.28 for male and 52.72 for female). Attending pre-primary education is much higher for those children living in municipality areas (44.63 percent) but surprising low for those living in rural area without road (3.91 percent). Laotian children seemed to have higher probability to attend preschool than other ethnic groups. Furthermore, grouping children according to their parents' educational attainment indicated that students living with parents who completed secondary education tended to be more likely to enroll in preschool. The ratio of preschool education enrollment of students living with mothers who had no education was 12.28 percent and for those living with fathers with no education was 4.33 percent. Additionally, the data show that only 9.35 percent of children from extremely poor households had similar access ${ }^{11}$.

To estimate accessibility or probability by controlling for a number of variables, a bivariate probit regression model was used to estimate the probability of accessing preschool education. The value of the dependent variable equals 1 if a child participated preschool education and 0 if a child did not. The estimate is divided into three groups - three-year-olds, four-year-olds, and lastly, a total sample of three- and four-year olds together ${ }^{12}$. Independent variables were obtained from children's characteristics, namely, gender, language group of household head, ethnicity of household head, family's place of residence, region, parents' educational attainment, and wealth, all of which can describe children's socioeconomic background.

The estimation in Table 2 shows that students living in higher income families tended to have more support from their family to pursue their preschool education. Especially, there was found significant probability of attending preschool among children from extremely wealthy families, by 29.1 percent compared to children from extremely poor families. Higher income of a family was a key factor in supporting children's access to preschool. In addition, the result shows that children living in urban areas had a higher probability of attending preschool than did a children living in rural areas without roads, by 7.73 percent.

Results indicate a significantly positive impact of the educational attainment of parents on students' probability of attending preschool. Students living with mothers who had completed secondary education tended to have a higher probability (by 4.72 percent) of attending preschool than did students living with mothers who had no education. Moreover, there was an even stronger likelihood (by 17.9 percent) for students living with mothers who had completed higher than secondary education to go to preschool than for students living with mothers who lacked such education to do so. The figure for children living with fathers with post-secondary education was 12.2 percent (higher than for children whose fathers lacked such education).

Interestingly, results indicate that mothers' educational attainment was found to have a greater impact on students' probability of attending preschool than did fathers' educational attainment, for both three- and four-year-olds. This suggests that mothers play a crucial role in childrearing and education, especially with regard to sending their children to school.

Table 1. Ratio of children's access to early childhood education by family background of three year-olds, four-year-olds, and both ages (percent)

\begin{tabular}{|c|c|c|c|}
\hline \multirow{2}{*}{ Variables } & \multicolumn{3}{|c|}{ Having participated in early childhood education } \\
\hline & Age 3 years & Age 4 years & Total \\
\hline \multicolumn{4}{|l|}{ Gender } \\
\hline Male & 11.66 & 22.52 & 47.28 \\
\hline Female & 12.41 & 28.83 & 52.72 \\
\hline \multicolumn{4}{|c|}{ Language group of household head } \\
\hline Lao-Tai & 24.41 & 43.22 & 74.9 \\
\hline
\end{tabular}




\begin{tabular}{|c|c|c|c|}
\hline Mon-Khmer & 4.07 & 13.49 & 17.43 \\
\hline Chinese-Tibetan & 4.67 & 14.15 & 2.79 \\
\hline Hmong-Mien & 2.71 & 9.52 & 4.88 \\
\hline \multicolumn{4}{|l|}{ Ethnicity of household head } \\
\hline Lao & 25.52 & 42.64 & 61.65 \\
\hline Khmu & 6.27 & 18.36 & 9.21 \\
\hline Hmong & 2.53 & 9.85 & 4.74 \\
\hline Other & 7.03 & 17.78 & 24.4 \\
\hline \multicolumn{4}{|l|}{ Residence } \\
\hline Urban & 38.69 & 65.74 & 44.63 \\
\hline Rural with road & 7.37 & 19.63 & 51.46 \\
\hline Rural without road & 2.46 & 9.52 & 3.91 \\
\hline \multicolumn{4}{|l|}{ Region } \\
\hline North & 10.97 & 26.46 & 42.68 \\
\hline Central & 18.39 & 32.54 & 46.72 \\
\hline South & 5.52 & 15.98 & 10.6 \\
\hline \multicolumn{4}{|l|}{ Mother's education attainment } \\
\hline None & 2.74 & 9.24 & 12.28 \\
\hline Primary & 8.14 & 22.06 & 33.89 \\
\hline Secondary & 30.31 & 59.77 & 35.7 \\
\hline Higher than secondary & 70.37 & 93.59 & 18.13 \\
\hline \multicolumn{4}{|l|}{ Father's education attainment } \\
\hline None & 1.92 & 7.10 & 4.33 \\
\hline Primary & 4.91 & 15.27 & 25.94 \\
\hline Secondary & 18.16 & 41.61 & 38.21 \\
\hline Higher than secondary & 49.48 & 74.86 & 31.52 \\
\hline \multicolumn{4}{|l|}{ Economic status } \\
\hline Extremely poor & 1.90 & 7.65 & 9.35 \\
\hline Poor & 4.01 & 14.48 & 11.58 \\
\hline Middle & 11.11 & 28.66 & 17.43 \\
\hline Wealthy & 21.83 & 46.81 & 23.01 \\
\hline Extremely wealthy & 62.16 & 83.08 & 38.63 \\
\hline Total (person) & 2,004 & 1,865 & 3,869 \\
\hline
\end{tabular}

Source: Authors' calculation from LSIS 2011-2012

Table 2. Estimation using Binary Probit Model (Marginal Effect) of access to early childhood education for three-year-olds, four-year-olds, and both ages

\begin{tabular}{cccc}
\hline Independent variables & Three-year-olds & Four-year-olds & Total \\
\hline Four-year-olds (reference: three-year-olds) & - & - & $0.157^{* * *}$ \\
& - & - & $(0.0121)$ \\
\hline Female (reference: Male) & 0.00861 & $0.0656^{* * *}$ & $0.0337^{* * *}$ \\
\hline Language (reference: Hmong-Mien) & $(0.0104)$ & $(0.0212)$ & $(0.0111)$ \\
\hline Lao-Tai language & & & \\
\hline Mon-Khmer language & 0.0471 & $0.999^{* * *}$ & $0.218^{*}$ \\
& $(0.0778)$ & $(0.000352)$ & $(0.130)$ \\
Chinese-Tibetan language & 0.0165 & $0.999^{* * *}$ & 0.176 \\
& $(0.0724)$ & $(0.000272)$ & $(0.132)$ \\
Ethnicity (reference: Others) & 0.00273 & $0.886^{* * *}$ & 0.134 \\
Lao ethnicity & $(0.0731)$ & $(0.00771)$ & $(0.170)$ \\
\hline
\end{tabular}




\begin{tabular}{|c|c|c|c|}
\hline & $(0.0173)$ & $(0.0390)$ & $(0.0192)$ \\
\hline \multirow{2}{*}{ Khmu ethnicity } & -0.0185 & -0.0260 & -0.0238 \\
\hline & $(0.0195)$ & $(0.0409)$ & $(0.0209)$ \\
\hline \multirow{2}{*}{ Hmong ethnicity } & -0.0437 & $0.957 * * *$ & 0.0466 \\
\hline & $(0.0382)$ & $(0.00450)$ & $(0.125)$ \\
\hline \multicolumn{4}{|c|}{ Area (reference: Rural without road) } \\
\hline \multirow[t]{2}{*}{ Urban } & $0.0737^{*}$ & $0.0919^{*}$ & $0.0849 * *$ \\
\hline & $(0.0410)$ & $(0.0554)$ & $(0.0333)$ \\
\hline \multirow[t]{2}{*}{ Rural with road } & 0.0165 & 0.00594 & 0.0128 \\
\hline & $(0.0206)$ & $(0.0364)$ & $(0.0201)$ \\
\hline \multicolumn{4}{|l|}{ Region (reference: South) } \\
\hline \multirow[t]{2}{*}{ North } & $0.0768 * * *$ & $0.187 * * *$ & $0.129 * * *$ \\
\hline & $(0.0229)$ & $(0.0407)$ & $(0.0226)$ \\
\hline \multirow[t]{2}{*}{ Central } & 0.0190 & 0.0367 & 0.0280 \\
\hline & $(0.0190)$ & $(0.0336)$ & $(0.0185)$ \\
\hline \multicolumn{4}{|c|}{ Mother's education attainment (reference: Uneducated) } \\
\hline \multirow{2}{*}{ Primary } & 0.00515 & 0.0265 & 0.0136 \\
\hline & $(0.0161)$ & $(0.0291)$ & $(0.0159)$ \\
\hline \multirow{2}{*}{ Secondary } & $0.0472 *$ & $0.138 * * *$ & $0.0848 * * *$ \\
\hline & $(0.0262)$ & $(0.0493)$ & $(0.0268)$ \\
\hline \multirow{2}{*}{ Higher than secondary } & $0.179 * * *$ & $0.473 * * *$ & $0.303 * * *$ \\
\hline & $(0.0671)$ & $(0.103)$ & $(0.0636)$ \\
\hline \multicolumn{4}{|c|}{ Father's education attainment (reference: Uneducated) } \\
\hline \multirow{2}{*}{ Primary } & 0.0125 & 0.0250 & 0.0181 \\
\hline & $(0.0220)$ & $(0.0363)$ & $(0.0205)$ \\
\hline \multirow{2}{*}{ Secondary } & 0.0416 & $0.132 * * *$ & $0.0816^{* * *}$ \\
\hline & $(0.0296)$ & $(0.0484)$ & $(0.0281)$ \\
\hline \multirow{2}{*}{ Higher than secondary } & $0.122 * *$ & $0.212 * * *$ & $0.177 * * *$ \\
\hline & $(0.0542)$ & $(0.0719)$ & $(0.0455)$ \\
\hline \multicolumn{4}{|c|}{ Economic status (reference: Extremely poor) } \\
\hline \multirow[t]{2}{*}{ Poor } & 0.00599 & $0.0722 * *$ & $0.0357^{*}$ \\
\hline & $(0.0195)$ & $(0.0341)$ & $(0.0194)$ \\
\hline \multirow{2}{*}{ Middle } & $0.0525 *$ & $0.195 * * *$ & $0.118 * * *$ \\
\hline & $(0.0273)$ & $(0.0435)$ & $(0.0263)$ \\
\hline \multirow{2}{*}{ Wealthy } & $0.0898 * *$ & $0.271 * * *$ & $0.181 * * *$ \\
\hline & $(0.0375)$ & $(0.0542)$ & $(0.0349)$ \\
\hline \multirow{2}{*}{ Extremely wealthy } & $0.291 * * *$ & $0.533 * * *$ & $0.441 * * *$ \\
\hline & $(0.0717)$ & $(0.0624)$ & $(0.0505)$ \\
\hline Pseudo R-squared & 0.3772 & 0.3280 & 0.3653 \\
\hline Observations & 2,004 & 1,865 & 3,869 \\
\hline
\end{tabular}

Remark: $* * * \mathrm{p}<0.01, * * \mathrm{p}<0.05, * \mathrm{p}<0.1$; Standard errors in parentheses.

Authors' computation. Data from the Lao Social Indicator Survey (LSIS) 2011-2012.

\section{Measuring Impacts on Child Development Outcomes}

To show the importance of education during preschool age in preparing children for compulsory education (primary level), this section will compare children's development with and without exposure to an early childhood education program. To measure development in early childhood, the LSIS developed an index called "Early Childhood Development Index (ECDI)"13. There are a ten yes/no questions used to determine whether children have achieved at least two of the criteria in each of four domains so as to be developmentally on tracks. The four domains in question are:

1) Cognitive readiness: (1) Children can identify/name at least ten letters of the alphabet, (2) they can read at 
least four simple and popular words, and (3) they know the name and recognize the symbols of all numbers from 1 to 10 .

2) Learning readiness: (1) Children can follow simple directions on how to do something correctly, and (2) when given something to do, are able to do it independently.

3) Physical readiness: (1) They can pick up a small object with two fingers, like a stick or a rock from the ground, and (2) the mother/caretaker does not indicate that the child is sometimes too sick to play.

4) Social-emotional readiness: (1) if the children can get along well with other children, (2) if they do not kick, bite, or hit other children, and (3) if they do not get easily distracted.

Table 3 presents assessment outcomes of children's development. On average, Lao children presented low cognitive skills in terms of learning readiness, physical readiness, and social-emotional readiness. However, children who received early childhood education seem to have higher cognitive skills than children who did not. However, development can vary, according to several factors, including a child's individual characteristics, family characteristics, and interaction with others. It is possible that there may have been some distortion in measuring development of children participating and those not participating in early childhood education. Hence, we applied another probit regression to estimate impacts of attending preprimary education on child development by controlling for the variables described below:

1) Children's characteristics including receiving early childhood education, gender, language spoken by the household head, and ethnicity of the household head

2) Family characteristics including residential area, region of the country, mother's educational attainment, father's educational attainment, and economic status

3) Activity with children including reading books to or looking at picture books with children, telling stories to children, singing songs to children or with children (including lullabies), taking children outside the home/compound/yard/enclosure, playing with children, and naming/counting/drawing things with children.

Table 3. Assessment of children's development outcomes of all children by socioeconomic variables (percent)

\begin{tabular}{|c|c|c|c|c|}
\hline Variables & Cognitive readiness & Learning readiness & Physical readiness & Social-emotional readiness \\
\hline \multicolumn{5}{|l|}{ Children's characteristic } \\
\hline \multicolumn{5}{|l|}{ Children's Age } \\
\hline three years old & 12.94 & 82.12 & 53.09 & 86.02 \\
\hline four years old & 22.71 & 81.13 & 52.62 & 86.15 \\
\hline \multicolumn{5}{|c|}{ Early Childhood Education } \\
\hline Received & 51.73 & 83.12 & 54.17 & 85.74 \\
\hline Not received & 8.47 & 81.27 & 52.53 & 86.17 \\
\hline \multicolumn{5}{|l|}{ Gender } \\
\hline Male & 16.61 & 82.61 & 56.85 & 85.95 \\
\hline Female & 18.65 & 80.57 & 48.38 & 86.23 \\
\hline \multicolumn{5}{|c|}{ Language spoken of household head } \\
\hline Lao-Tai & 19.82 & 85.98 & 51.30 & 86.21 \\
\hline Mon-Khmer & 13.41 & 81.73 & 48.95 & 85.74 \\
\hline Hmong-Mien & 20.78 & 77.13 & 57.69 & 89.03 \\
\hline Chinese-Tibetan & 17.50 & 66.51 & 71.63 & 77.65 \\
\hline \multicolumn{5}{|c|}{ Ethnicity of household head } \\
\hline Lao & 19.83 & 86.99 & 48.81 & 85.04 \\
\hline Khmu & 15.09 & 86.94 & 50.90 & 82.43 \\
\hline Hmong & 21.35 & 76.83 & 57.94 & 89.05 \\
\hline Other & 14.83 & 76.67 & 54.99 & 87.36 \\
\hline \multicolumn{5}{|l|}{ Family characteristic } \\
\hline \multicolumn{5}{|l|}{ Residence } \\
\hline Urban & 40.70 & 83.33 & 52.87 & 88.14 \\
\hline Rural with road & 14.03 & 81.58 & 52.93 & 85.94 \\
\hline Rural without road & 5.39 & 79.71 & 52.54 & 83.94 \\
\hline
\end{tabular}




\begin{tabular}{|c|c|c|c|c|}
\hline \multicolumn{5}{|l|}{ Region } \\
\hline North & 16.35 & 79.89 & 59.58 & 85.11 \\
\hline Central & 21.75 & 80.19 & 47.70 & 88.94 \\
\hline South & 11.58 & 89.13 & 46.20 & 81.78 \\
\hline \multicolumn{5}{|c|}{ Mother's education attainment } \\
\hline None & 14.88 & 76.09 & 53.47 & 84.22 \\
\hline Primary & 18.19 & 84.00 & 53.09 & 87.09 \\
\hline Secondary & 19.44 & 87.18 & 51.87 & 89.16 \\
\hline Higher than secondary & 30.28 & 92.96 & 48.59 & 82.61 \\
\hline \multicolumn{5}{|c|}{ Father's education attainment } \\
\hline None & 15.69 & 74.84 & 53.86 & 84.21 \\
\hline Primary & 16.34 & 83.33 & 52.39 & 86.03 \\
\hline Secondary & 19.32 & 84.57 & 53.27 & 87.21 \\
\hline Higher than secondary & 22.76 & 78.86 & 52.37 & 86.80 \\
\hline \multicolumn{5}{|l|}{ Economic status } \\
\hline Extremely poor & 6.76 & 79.22 & 52.38 & 86.19 \\
\hline Poor & 9.02 & 81.33 & 53.32 & 83.22 \\
\hline Middle & 19.15 & 85.04 & 52.10 & 86.36 \\
\hline Wealthy & 29.77 & 84.53 & 55.20 & 86.57 \\
\hline Extremely wealthy & 52.93 & 82.01 & 51.99 & 90.38 \\
\hline \multicolumn{5}{|l|}{ Breast feeding } \\
\hline Breastfed & 17.39 & 81.71 & 53.01 & 86.31 \\
\hline Non-breastfed & 25.71 & 78.87 & 46.48 & 76.39 \\
\hline
\end{tabular}

\begin{tabular}{|c|c|c|c|c|}
\hline \multicolumn{5}{|l|}{ Activity with children } \\
\hline \multicolumn{5}{|c|}{ Read books to or look at picture books with children } \\
\hline Mother & 41.04 & 84.52 & 50.30 & 87.34 \\
\hline Father & 35.73 & 81.79 & 50.36 & 85.21 \\
\hline Other & 26.31 & 82.59 & 54.06 & 85.06 \\
\hline Nobody & 15.42 & 79.00 & 53.60 & 84.33 \\
\hline \multicolumn{5}{|l|}{ Tell stories to children } \\
\hline Mother & 31.11 & 83.24 & 53.63 & 85.32 \\
\hline Father & 24.85 & 80.09 & 52.80 & 83.71 \\
\hline Other & 21.84 & 81.18 & 53.45 & 85.14 \\
\hline Nobody & 17.20 & 78.06 & 50.42 & 87.27 \\
\hline \multicolumn{5}{|c|}{ Sing songs to children or with children, including lullabies (reference: Nobody) } \\
\hline Mother & 32.05 & 82.64 & 52.74 & 86.28 \\
\hline Father & 25.66 & 80.00 & 51.15 & 84.01 \\
\hline Other & 21.42 & 80.82 & 53.44 & 85.54 \\
\hline Nobody & 15.27 & 78.04 & 51.65 & 86.80 \\
\hline \multicolumn{5}{|c|}{ Take children outside the home/compound/yard/enclosure (reference: Nobody) } \\
\hline Mother & 21.25 & 80.73 & 53.42 & 87.60 \\
\hline Father & 21.35 & 80.06 & 52.63 & 85.37 \\
\hline Other & 16.80 & 81.12 & 52.41 & 86.81 \\
\hline Nobody & 15.86 & 79.04 & 53.98 & 85.34 \\
\hline \multicolumn{5}{|c|}{ Play with children (reference: Nobody) } \\
\hline Mother & 19.97 & 81.17 & 52.28 & 87.14 \\
\hline Father & 19.40 & 82.88 & 53.26 & 85.70 \\
\hline Other & 17.60 & 81.76 & 53.04 & 86.64 \\
\hline Nobody & 17.93 & 77.38 & 52.26 & 86.67 \\
\hline
\end{tabular}




\begin{tabular}{ccccc}
\hline Mother & 29.04 & 81.93 & 54.80 & 88.06 \\
Father & 27.74 & 80.99 & 54.07 & 85.16 \\
Other & 23.92 & 82.09 & 53.73 & 86.53 \\
Nobody & 15.52 & 79.90 & 51.24 & 83.41 \\
\hline Observations & 3,302 & 3,352 & 3,344 & 3,132 \\
\hline
\end{tabular}

Source: Authors' calculations from LSIS 2012

Our estimations show that children who attended preschool tended to have statistically significant on a higher probability of cognitive readiness (by 21.7 percent) but a lower probability of social-emotional readiness (by 3.38 percent) than children who did not go to preschool (Table 3). In this case, children may have limitations in their ability to learn and face exclusion from learning environments from preschool which will effect to their social-emotional development (Brown et al., 2012).

Results also suggest that when mothers had completed higher than secondary education, their children were more likely to have cognitive skills (by 8.05 percent) and also learning skills (by 12 percent) than children living with mothers who were uneducated. We also found that children living with fathers who had completed primary education had 2.84 percent higher probability of learning readiness than children living with fathers who were uneducated.

As for economic status, the estimation found that children from high-income families were more likely to have cognitive readiness than children from extremely poor families. Especially, children from extremely wealthy families had significantly higher probability of social-emotional readiness than children from extremely poor families by 5.56 percent. In addition, children who were breastfed had 8.77 percent higher probability of social-emotional readiness than children who were not breastfed.

Nevertheless, the binary probit estimation above does not consider the problem of endogeneity - children also might have self-selected to attend preschool. This issue may affect the estimation of the model and thus bias the results. Therefore, to prevent a biased estimation, we separated our data into two groups - three-year-olds and four-year-olds. In this case, children begin to undergo early childhood education at the age of three, while variables relating to development measured data on four-year-olds, which is a one-way relationship. Development of children at the age of five reflects no impact from attending preschool when the children were three-year-olds.

Table 4 also presents an econometric estimation of variables affecting development of three- and four-year-olds using the binary probit model. Results show that children of both ages who received early childhood education had significantly higher probability of cognitive readiness than children who did not (by 14.7 percent for three-year-olds and 28.5 percent for four-year-olds).

As for variables relating to parents or other household members doing activities with children, reading books to children or looking at picture books with three-year-olds and naming/counting/drawing things with four-yearolds showed higher probability of promoting cognitive readiness than was found among children who had nobody doing these activities with them. And children with mothers who did activities with them at age four had a higher probability of increasing their cognitive skills, especially when mothers tell them the stories, sing songs, and name/count/draw things with them than did children who had no one doing these kind of activities with them.

However, it was also found that when fathers or others took children outside the home, they were more likely to experience a negative impact on cognitive readiness than did children who were not taken outside. Even though fathers playing with children tended to lower children's cognitive skills, it had a positive impact on learning skills and physical skills. All in all, however, mothers doing activities with children had a higher probability of increasing social-emotional readiness when compared with fathers doing similar activities.

\section{Conclusion and Policy Recommendations}

This study examines the impact of socioeconomic factors on the accessibility of early childhood education and child development outcomes in Lao PDR, a least developed country. Our estimation has shown that children who live in municipal areas had a higher probability of attending preschool than did those living in rural areas without roads. Interestingly, mothers' educational attainment was found to have a greater impact on students' probability of attending preschool than did fathers'. In addition, a family's economic status was observed to have an important impact on their children's preschool enrollment. Children from high-income families had a higher probability of attending preschool than did children from extremely low-income families. 


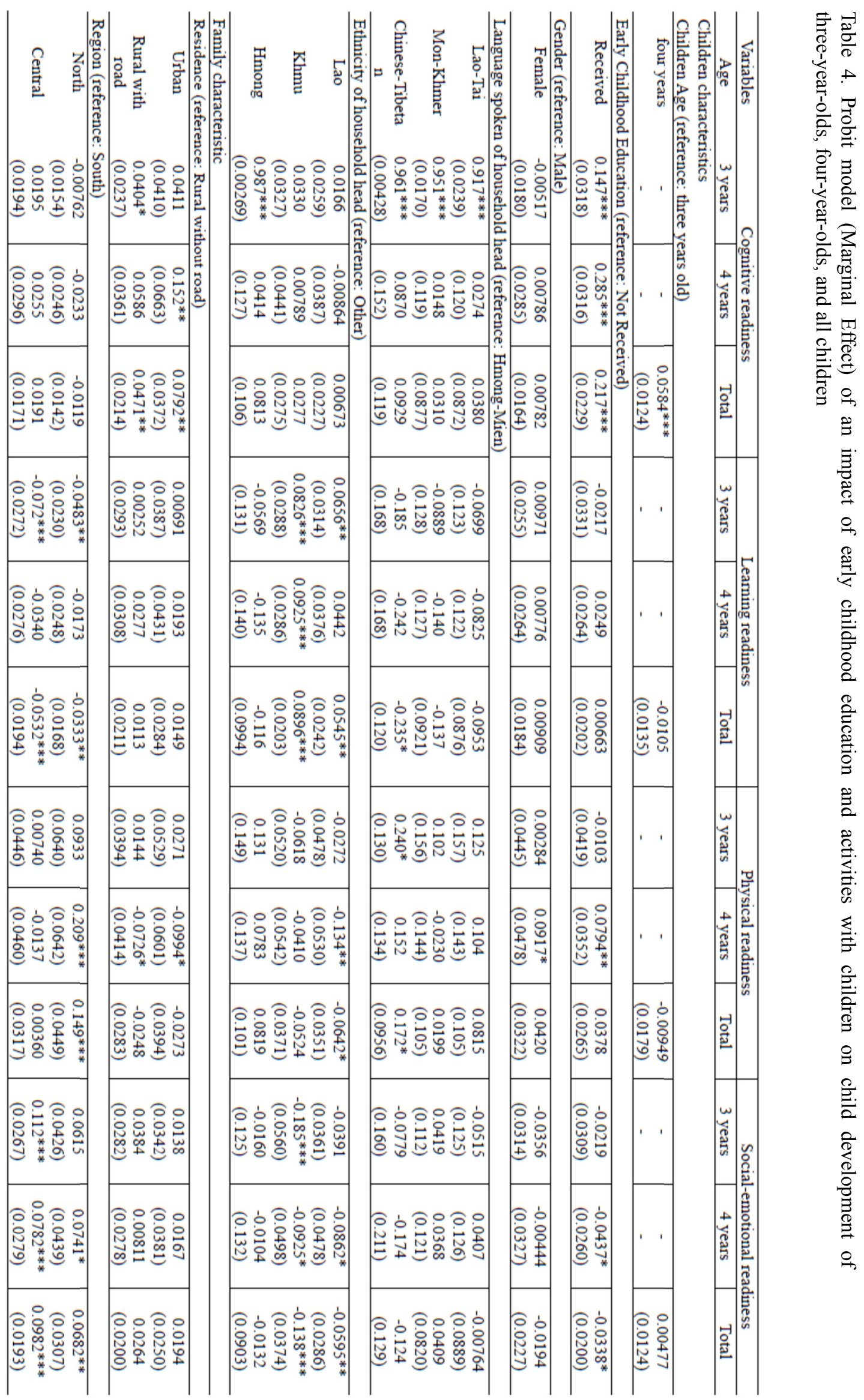




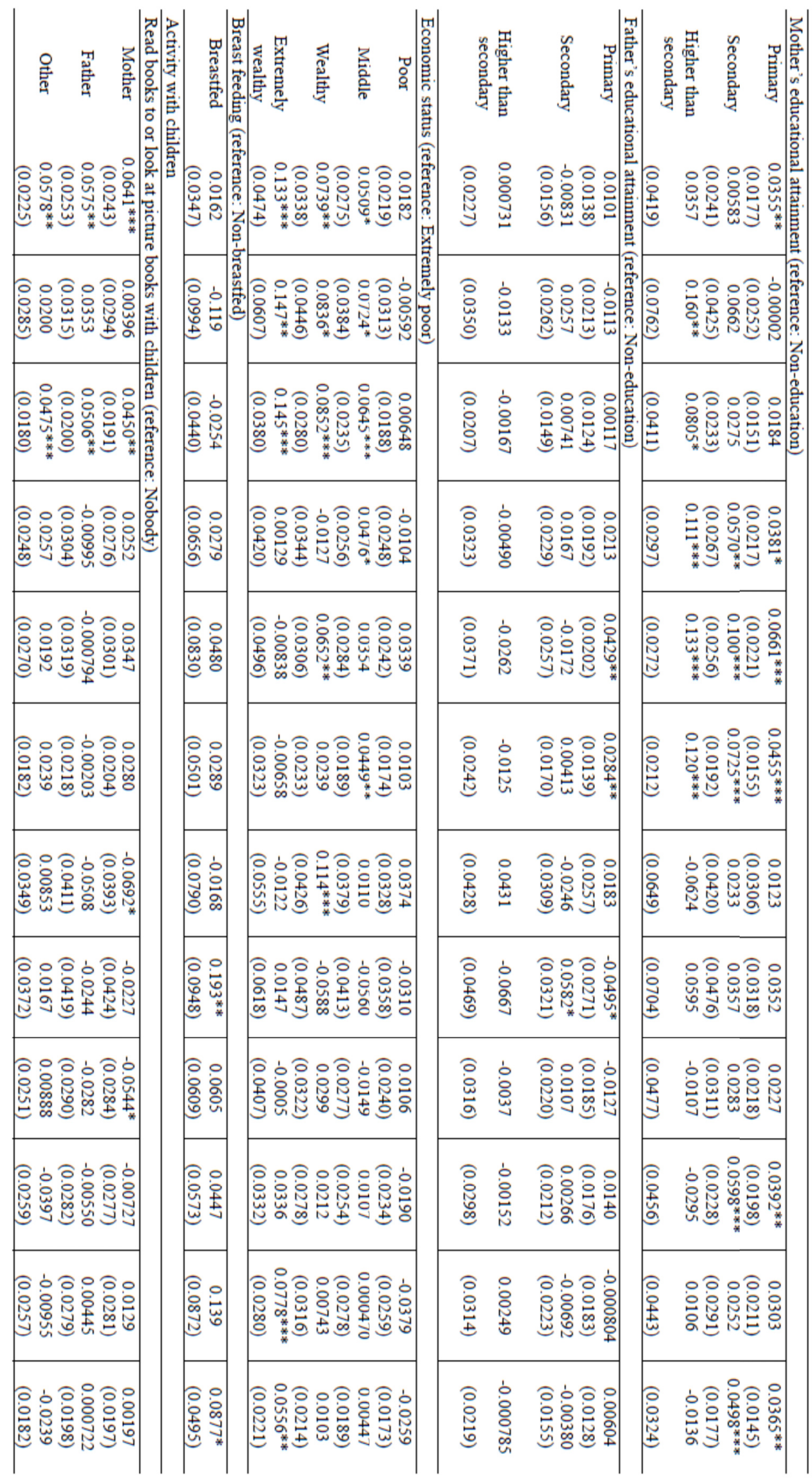




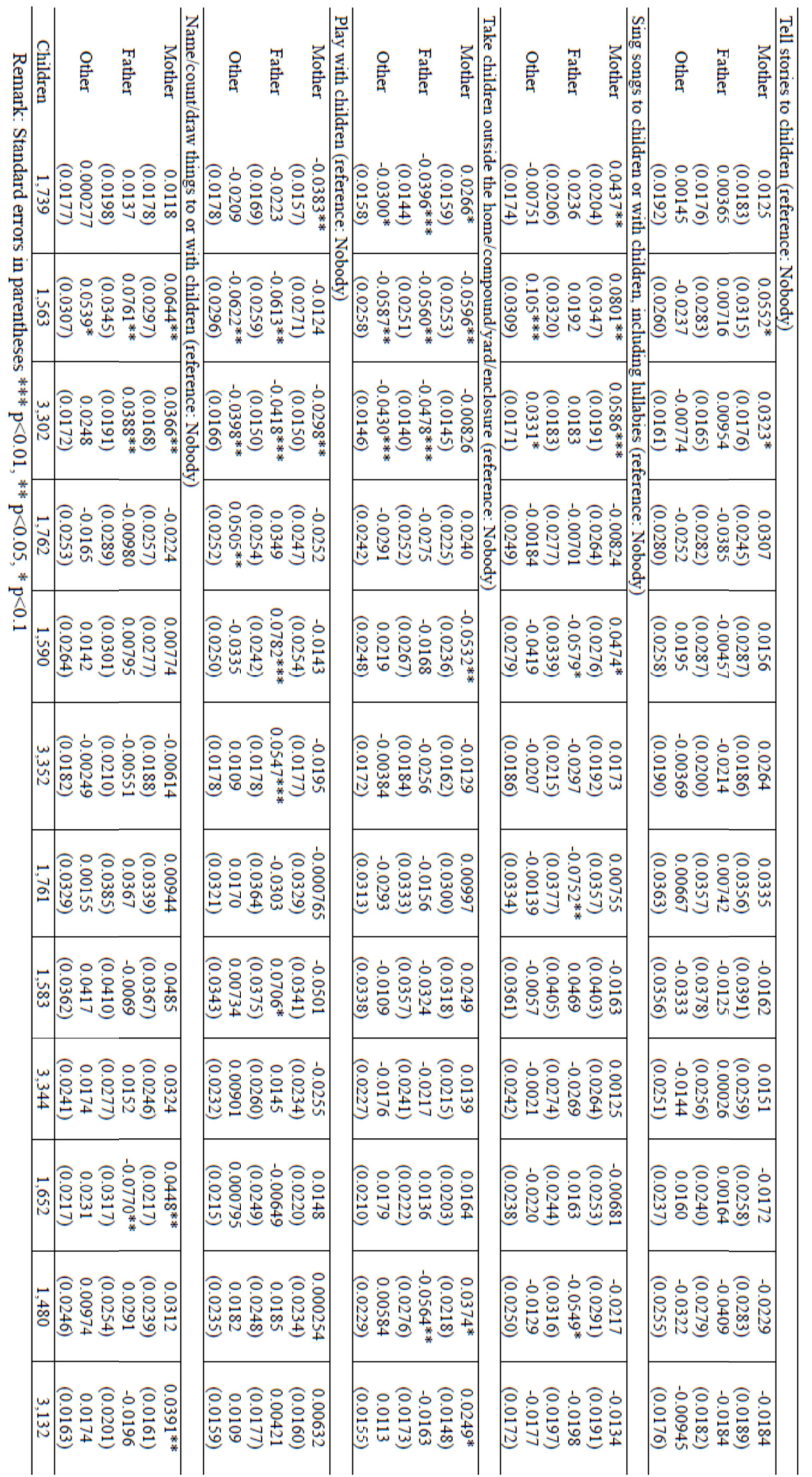


Our investigation of children's development outcomes in Laos reveals that four-year-olds had a higher probability of attaining cognitive readiness than did three-year-olds. Results indicate that children who participated in early childhood education were likely to have significantly higher cognitive readiness than children who did not participate in early childhood education whether early or later but that they faced social-emotional problems when they reached age four. Regarding parents' educational attainment, we find that children living with mothers who were educated tended to have higher cognitive and learning readiness than children living with mothers who were relatively uneducated.

Results also indicate that children from high-income families had a higher probability of achieving cognitive readiness than children from extremely poor families. Especially, children from extremely wealthy families were likely to have greater social-emotional readiness than were children from extremely poor families. Furthermore, activities done together between parents and children also play an important role in their children's development.

Since socioeconomic factors influence children's preschool enrollment in Lao PDR, which serves here as a case study of a least-developed country, the government should promote early childhood educational opportunities for disadvantaged children in order to reduce the gap in access to early education between urban and rural children. Besides overall support for early childhood education, preschool quality in terms of curriculum and personnel is also a considerable issue that affects children's development. Thus, investing in early childhood education should be considered an economic and social development policy for strengthening employment productivity that will benefit the country in the long-term.

Our data are limited by the fact that there is no information on preschool quality and also no separate data on public and private preschools, which would allow for exploration of the impact of different levels of quality and types of early childhood education on children's development. Moreover, this investigation would require panel data for each individual in order to assess the long-term benefits of early childhood education, which would generate useful information for researchers as they craft recommendations for education policy.

\section{References}

Acemoglu, D., \& Autor, D. (2011). Introduction to Human Capital Investments. Lectures in labor economics (pp. 3-26). Retrieved from http://economics.mit.edu/files/4689

Banerji, A., Cunningham, W., Fiszbein, A., King, E., Patrinos, H., Robalino, D., \& Tan. J. P. (2010). Stepping up skills for more jobs and higher productivity. Washington, D.C: The World Bank.

Berlinski, S., Galiani, S., \& Manacorda, M. (2008). Giving children a better start: Preschool attendance and school-age profiles. Journal of Public Economics, 92(5-6), 1416-1440. https://doi.org/10.1016/j.jpubeco.2007.10.007

Besharov, D. J., Higney, C. A., \& Call, D. M. (2011). Chicago Child-Parent Center (CPC). Assessments of Twenty-Sex Early Childhood Evaluations (pp. 3-40). Retrieved from http://www.welfareacademy.org/pubs/early_education/pdfs/Besharov_ECE\%20Assessments_Chicago_Chil d-Parent_Center.pdf.

Campbell, F. A., \& Ramey, C. T. (2007). The Abecedarian Project. In A. J. Reynolds, A. Rolnick, M. M. Englund \& J. Temple (Eds.), Cost effective programs in children's first decade: A human capital integration (pp. 76-95). New York: Cambridge University Press.

Hanushek, E. A., \& Woessmann, L. (2012). Do better schools lead to more growth? Cognitive skills, economic outcomes, and causation. Journal of Economic Growth, 17(4), 267-321. https://doi.org/10.1007/s10887-012-9081-x

Heckman, J. J., Moon, S. H., Pinto, R., Savelyev, P. A., \& Yavitz, A. (2010). The rate of return to the HighScope Perry Preschool Program. Journal of Public Economics, 94(1-2), 114-128. https://doi.org/10.1016/j.jpubeco.2009.11.001

King, E. M., \& Walle, D. (2010). Laos: Ethno-linguistic Diversity and Disadvantage The Lao People's Democratic Republic. Indigenous Peoples, Poverty and development (pp. 1-17). Retrieved from http:// siteresources.worldbank.org/EXTINDPEOPLE/Resources/4078011271860301656/Chapter_7_Laos.pdf.

Loeb, S., Bridges, M., Bassok, D., Fuller, B., \& Rumberger, R. W. (2007). How much is too much? The influence of preschool centers on children's social and cognitive development. Economics of Education Review, 26(1), 52-66. https://doi.org/10.1016/j.econedurev.2005.11.005

Loeb, S., Fuller, B., Kagan, S. L., \& Carrol, B. (2004). Child Care in Poor Communities: Early Learning Effects of Type, Quality, and Stability. Child Development, 75(1), 47-65. 
https://doi.org/10.1111/j.1467-8624.2004.00653.x

MacEwan, A. (2013). Early childhood education, economic development, and the need for universal programs: With a focus on New England. Economics, Management and Financial Markets, 10(1), 9-11.

Nath, S. R., \& Sylva, K. (2007). Children's access to pre-school education in Bangladesh. International Journal of Early Years Education, 15(3), 275-295. https://doi.org/10.1080/09669760701516967

Nonoyama-Tarumi, Y., \& Ota, Y. (2011). Early childhood development in developing countries: Pre-primary education, parenting, and health care. Retrieved from http://unesdoc.unesco.org/images/0019/001912/191223e.pdf

Opel, A., Ameer, S. S., \&Aboud, F. E. (2009). The effect of preschool dialogic reading on vocabulary among rural Bangladeshi children. International Journal of Educational Research, 48(1), 12-20. https://doi.org/10.1016/j.ijer.2009.02.008

Pholphirul, P. (2017). Pre-primary education and long-term education performance: Evidence from Programme for International Student Assessment (PISA) Thailand. Journal of Early Childhood Research, 15(4), 410-432. https://doi.org/10.1177/1476718X15616834.

Rao, N., \& Pearson, E. (2007). An Evaluation of Early Childhood Care and Education Programmes in Cambodia. Phnom Penh: UNICEF.

Santibañez, L., Vernez, G., \& Razquin, P. (2005). Education in Mexico: Challenges and Opportunities. Retrieved from http://www.rand.org/content/dam/rand/pubs/documented_briefings/2005/RAND_DB480.pdf

Siraj-Blatchford, I., Sylva, K., Taggart, B., Melhuish, E., Sammons, P., \& Elliot, K. (2004). The Effective Provision of Pre-School Education (EPPE) Project: Findings from the pre-school to end of key stage 1. Nottingham: Department for Education and Skills.

Stoop, G. (2011). Positive Foundations for Learning: Confident and Competent Children in Early Childhood Services. Wellington: Crown Education Evaluation.

UNESCO. (2006). Strong foundations: early childhood care and education. Paris: UNESCO.

UNESCO. (2015). Education for All 2015 National Review: Country Report of Lao PDR. Vientiane: UNESCO.

UNICEF. (2012). School readiness: A Conceptual Framework. JAMA Pediatrics, 167(8), 1-40.

World Bank. (2015). Improving learning outcomes through early childhood development. Education Global Practice. Washington, D.C.: The World Bank.

\section{Copyrights}

Copyright for this article is retained by the author(s), with first publication rights granted to the journal.

This is an open-access article distributed under the terms and conditions of the Creative Commons Attribution license (http://creativecommons.org/licenses/by/4.0/).

\section{Notes}

Note ${ }^{1}$.The "Skills Toward Employment and Productivity" STEP framework is a simple conceptual framework focused on 5 interlinked steps including Step 1: Getting children off to the right start; Step 2: Ensuring that all students learn; Step 3: Building job-relevant skills that employers demand; Step 4: Encouraging entrepreneurship and innovation; and Step 5: Matching the supply of skills with the demand (Banerji, 2010)

Note ${ }^{2}$. However, a study by Loeb et al. (2004) has found negative impacts of early childhood education. They found that even though children who had attended preschool tended to have higher cognitive scores, such children tended to exhibit more aggressive behavior compared to those children who did not participate in preschool. Early childhood programs could have negative effects on social behavior (Loeb et al., 2007).

Note ${ }^{3}$. The Effective Provision of Pre-School Education (EPPE) project is the first major European longitudinal study of a national sample of young children's development between the ages of 3 and 7 years to investigate the effects of pre-school education on 3,000 children

Note ${ }^{4}$. The Carolina Abecedarian Project was an extension of the Perry Preschool Project and carried out by the University of North Carolina's FPG Child Development Institute from 1972 to 1977. It intended to improve the 
language skills of children from their infancy to five years of age(Campbell \& Ramey 2007)

Note ${ }^{5}$. The Chicago Child-Parent Center Program was implemented in 1967.It provided preschool education for children from disadvantaged families. Parent participation was required on Sundays. Currently, there are still 11 schools hosting this program in Chicago (Besharov, Higney, \& Call 2011)

Note ${ }^{6}$. The Perry Preschool Project was conducted from 1962 to 1967 with the main objective of providing preschool education to disadvantaged African American children. School activities focusing on developing students' skills as well as parent participation were particularly encouraged (Heckman, Moon, Pinto, Savelyev, \& Yavitz, 2010).

Note ${ }^{7}$.Although community-based early childhood education is provided by the Education Department, it is not the same standard as formal early childhood education classes because the caregivers are not trained as formal teachers. This has become a serious problem for disadvantaged children in poor communities and remote areas in Laos (UNESCO, 2015).

Note ${ }^{8}$. For the analysis of Early Childhood Care and Education (ECCE), this study uses data from questionnaires focusing on the household and children under five. The questionnaire for all children under five asked about mothers or caretakers who care for a child under the age of 5 years and who lives with such children

Note ${ }^{9}$.The scope of the LSIS 2011-2012 included private households in Lao PDR, men and women 15-49 years old, and children under five years old. For the analysis of Early Childhood Care and Education (ECCE), this study uses data from questionnaires focusing on the household and children under five. The household questionnaire provides data on household composition, location of residence, household wealth and education level, and schooling of household members. The questionnaire for all children under five and each child in the household collected data on early learning, child development, and immunization. This questionnaire asked about mothers or caretakers who care for a child under the age of 5 years and who lives with such children. The questionnaires were designed and developed in both Lao and English by Lao Statistics Bureau (LSB) and based on the questionnaires of Multiple Indicator Cluster Survey (MICS) and Demographic and Health Surveys (DHS) developed by UNICEF. Data collected in face-to-face mode by interviewing households on the operation list which were conducted by 70 operators recruited and trained from LSB. Data collectors are the member of Department of Statistics, Ministry of Planning and Investment, and Ministry of Health.

Note ${ }^{10}$. Household wealth is constructed using principal component analysis and includes several items, such as what material is used for a dwelling's floor, number of rooms in dwelling, main source of drinking water, toilet facility used, and presence of electricity, radio, television, or refrigerator. In addition, questions were asked about whether any members of household own a bicycle or car, and what main cooking fuel was used. Therefore, we have categorized indicators into five levels: (1) extremely poor, (2) poor, (3) middle, (4) wealthy, and (5) extremely wealthy, with the lowest 20 quintile referring to samples with extremely poor status, while the highest 20 quintile referring to samples with extremely wealthy status

Note ${ }^{11}$. Since preschool education is not compulsory in Lao PDR, it is reasonable to assume that accessibility to early childhood education is largely determined by socioeconomic factors of children's families. However, in the LSIS survey, questions concerning early childhood education asked only whether a child attended any organized learning or early childhood education program, such as a private or government facility, including kindergarten or community child care.

Note ${ }^{12}$. The reason a sample of four-year-olds is analyzed separately here is that there is a tendency, due to the fact that preschool education is non-compulsory, for some children to not start their early childhood education in their first year of kindergarten, but to start preschool in a later year (second or third year).

Note ${ }^{13}$.The Early Child Development Index (ECDI) launched a data revolution for the Sustainable Development Goals and is used as an index of developmental potential in early childhood, currently represented in the Multiple Indicator Cluster Survey (MICS) that assesses children aged 36-59 months in four domains. Each of these four domains is measured through instruments based on real time observation, which refers to the ability of children in cognitive readiness, physical readiness, learning readiness, and social-emotional readiness. The MICS surveys calculates an overall Index Score as the percentage of children aged 36-59 months who are on track in at least three of four domains(UNESCO, 2015). 